\title{
Alignment of Curriculum, Outcomes, and Standards in Vietnamese English Language Teacher Education
}

\author{
Thi Phuong Lan Nguyen, Quang Vu \\ Hanoi Pedagogical University No.2, Vietnam
}

\begin{abstract}
The English Language Teaching (ELT) in Vietnam has been improving significantly in response to the requirements of a rapidly evolving socioeconomic context. Vietnamese government is playing a leading role in the readiness for developing the English Language Teacher Education (ELTE) in the globalisation and socialisation contexts. However, there are still disparities between the institutional curriculum, expected outcomes, and the national standards for the ELTE graduated students. The project was conducted to explore the link between and among the key elements of Vietnamese ELTE programs. A mixed-method approach with three tools of collecting and analysing data were employed to obtain understandings of the policies and practices at the national and institutional levels. The data collected from eleven participating institutions across Northern, Central, and Southern regions of Vietnam may provide government and institutional stakeholders a better appreciation of how well their curriculum, outcomes, and the standards required by the Ministry of Education and Training (MoET) are aligned. The significance of the project lies in its relevance to the English language teaching careers in Vietnamese specific context and in other countries where English language is taught as a foreign language.
\end{abstract}

\section{Introduction}

In the new context of globalisation and socialisation, like other neighboring Asian countries, Vietnam has been pushing to develop English Language Teaching (ELT) at all levels. The Vietnamese National Foreign Language Project 2020 (known as Project 2020) commenced in 2008 to develop the capacity of a foreign language use by all graduates from vocational schools, colleges, and universities. The graduates must be prepared to be more confident in communication using foreign languages. Project 2020 aims to renovate the foreign languages teaching and learning, as well as improving training programs to fit with specific levels.
Project 2020 aims to enrich and upgrade the language capacity of the human resources and to diversify the pedagogies to meet learners' needs. Project 2020 was largely invested, with approximately five billion US dollars [1].

Despite high levels of investment, the ELTE institutional reported outcomes have not met their expectations, especially in terms of English language proficiency and employability skills.

Not many graduates could meet the national English Language Proficiency (ELP) requirements. Previous Vietnamese studies have confirmed ELTE graduates' failure to meet national standards [2] [3] [4]. Students' lack of ELP attainment was stated in evaluation reports of the National Foreign Languages Project 2020 [5] [6]. Vietnamese institutions have been challenged in assisting students who entered programs with below B1 to attain the $\mathrm{C} 1$ level at graduation [7]. Students' failure to meet MoET's standards constrains graduates seeking employment which requires proficiency in English [8].

The Vietnamese higher education system is also reported not to prepare students with sufficient employability preparation [9] [10] [11].

\section{Requirements for graduates of the English Language Teacher Education Programs}

ELTE shares the centralised implementation with other South-East Asian countries but the outcomes and standards are varied at institutional level. Institutions may interpret the national requirements to fit with their specific teaching and learning contexts [12]. Tertiary education aims at training students who possess political awareness, ethics, knowledge, professional skills, research capacity, and ICT competence corresponding to their level, creativity, professional responsibility, adaptability, and willingness to serve people. Tertiary education specifies providing students with comprehensive professional knowledge, a thorough grasp of the natural and social law and principles, basic 
practical skills and the ability to work independently, creatively, and solve problems [13].

MoET defines professional knowledge, practical skills and performance, technological cognitive abilities, and problem solving as learning outcomes. Learning outcomes and standards also include employability after graduation and specific program requirements. Outcomes and/or standards must include fulfilling requirements related to (i) knowledge, (ii) skills, (iii) dispositions, (iv) employability, and (v) lifelong learning abilities [14].

Content knowledge covers foundation and professional knowledge, for example, Vietnamese culture, pedagogy, psychology, English knowledge, and language teaching methodology. English knowledge includes linguistics (e.g., phonetics, vocabulary, semantics, syntax, grammar, etc.) and social-cultural knowledge (e.g., British and American geography, civilization, culture, inter-culture, and arts, etc. English knowledge may also include knowledge of English language communicative, learner profiles, and general linguistics science.

Graduates are also required professional knowledge which means the language learning theory and English language teaching methodology. The professional knowledge may cover knowledge of pedagogical psychology, educational and managerial approaches to educating students; or it may be grouped into knowledge of English teaching, language teaching theory, planning and organising learning activities, curriculum, and applying IT in English language teaching.

Skills standards required for the tertiary education graduates included basic and soft skills. Basic skills include English language communication, pedagogical, and research skills. Soft-skills include those related to teaching (presentation, critical thinking, and teamworking skills), information technology (IT) skills, and skills of social integration.

English language proficiency skills standards as outlined in Decision No.1400 require undergraduate institutions students to attain Level 5 of the six levels of the Common European Framework of Reference for Languages (CEFR) (the $\mathrm{C} 1$ level) upon graduation from 4-year Bachelor programs [1]. In addition, the Decision on the Approval of Adjustment and Supplement of the Project entitled "Teaching and Learning Foreign Languages in the National Education System, Period 2017-2025" stipulates that ELP standards will be implemented for all graduates by 2025 [15].

Disposition standards are divided into three groups, (i) personal dispositions mean living and working under the law, being responsible for themselves and for family, etc.); (ii) professional dispositions mean love for teaching, having the will to improve knowledge and skills, loving and respecting students' opinion, etc.); and (iii) social dispositions mean having a healthy lifestyle and being consistent with national identity and their teaching career, etc.)

Employability refers to sufficient competence to be a teacher in any Vietnamese education sector (primary, secondary, and high school), and vocational and tertiary education. Employability also refers to roles such as interpreters, translators, or staff in cultural hospitality related companies or capacity of working in other roles associated with education, for example, journalism and media requiring the English language use.

Life-long learning is sometimes simply used as the capacity of continuous learning and studying in linguistics related programs (e.g., contrastive linguistics or applied linguistics) and including upgrading to Postgraduate programs. However, it may be used as the capacity to accumulate and apply what they have learnt for further study and research, either domestic or overseas; to apply what they have learnt to approach, grasp, and apply in disciplinary fields which are underresearched; and to access scientific knowledge, new technology to improve personal and social needs, to improve professional and managerial roles in the education system.

Outcomes of ELTE programs designed by institutions must be in accordance with the requirements of Vietnamese MoET and with the mission of each specific institution. However, there is a large variation in implying the key terms stated in the MoET's standards in institutional level. For example, the term 'English knowledge' may be interpreted as English knowledge relatively in language skills, grammar, semantics and translation, or the capacity of handling proficient knowledge in the process of communication with foreigners, translation, teaching English at all levels to meet the standards for beginning teachers.

Vietnamese MoET has approved the core national standards for pedagogical institutions' graduates, which identify the graduated students' required knowledge, skills, and dispositions. However, the institutions, during process of building their outcomes often interpret in a way to fit their teaching and learning context. Therefore, outcomes may vary from institution to institution because some standards may have been ignored or alternatively interpreted from MoET standards.

\section{Methodology}

A mixed-methods approach was conducted with three tools of collecting and analysing data to answer the research question "To what extent, are curriculum, outcomes and standards of ELTE Programs aligned?" The sources of the data consisted of governmental and institutional documents, survey, and interviews with 
ELTE lecturers and administrators in order to construct a deeper understanding of the complexities of ELTE policy implementation [16] and alignment across sectors of Vietnamese MoET.

The study was conducted in all major parts of Vietnam, from the North, to the Central to the South. The participants of the study were lecturers, administrators and instructional leaders from the eleven participating institutions, four of which are provincial institutions and the seven are metropolitan ones.

Documents at both ministerial and institutional levels regarding curriculum, outcomes and standards in the period of 2008 to 2016 have been collected and analysed.

\section{The significant findings}

Significant findings of the alignment between curriculum, institutional outcomes and MoET's standards will be presented in this section, in which English language knowledge, English language proficiency skills, and employability skills have been reported remaining low performance.

\subsection{The participants' perceptions of high aim English language proficiency standards}

A majority of the participating interviewees highlighted their worries about the standards of English language proficiency (the $\mathrm{C} 1$ level). Interviewees believed that the $\mathrm{C} 1$ level is reasonable or achievable for Vietnamese ELTE graduates. More than half of interviewees shared the same idea that the $\mathrm{C} 1$ level is too far from their students' English language proficiency levels. The participating lecturers believed that the students' low entry level might prevent students from achieving the $\mathrm{C} 1$ level.

The participants also showed their concern that students could not graduate the ELTE program with such a high-level requirement. Nearly half of the informants perceived that it would be more reasonable if the standard lowered to the B2 (level 4/6). Some informants reported that less than $50 \%$ of their students may achieve the B2 level, and the others may be able to achieve the B1 level after re-taking the tests a number of times. The participants were not confident with their students' capacity of achieving the $\mathrm{C} 1$ level as required. They expressed their frustration with the MoET's English language proficiency standard and stated that the $\mathrm{C} 1$ level was unattainable in every single area, not only in provincial institutions. On average, the participants perceived that $57 \%$ of their students failed to attain the $\mathrm{C} 1$ level standard.

\subsection{The participants' perceptions of the alignment between the institutional outcomes and MoET's standards}

A large number of surveyed respondents felt satisfied with the alignment between their expected outcomes and MoET's standards in terms of the general English language knowledge. $91.45 \%$ of the respondents agreed with the principle that the outcomes clearly identified the requirements of English language knowledge (Table 1).

The surveyed respondents were also likely to agree with the strong alignment between their outcomes and MoET's standards in terms of English language skills. For example, $93.42 \%$ of the surveyed respondents agreed that their institutional outcomes already clarified the requirements of English language communicative skills. In addition, a high percentage of respondents agreed with the principle that English language competency requirements, the $C 1$ level, is identified in their institutions' outcomes, at $88.82 \%$ (Table 1).

The participants indicated their high satisfaction with the identification of the employability in their institutional outcomes. $87.42 \%$ of the surveyed lecturers agreed that the outcome identified the students' employability. $78.67 \%$ of the respondents agreed that the outcomes clearly identified the graduate teacher students' professional practical experience requirements within high school and other teaching sites.

Table 1: Participants' perceptions of the alignment between institutional outcomes and MoET's standards

\begin{tabular}{|c|c|c|}
\hline $\begin{array}{c}\text { Do you agree or disagree } \\
\text { with the following } \\
\text { statements? }\end{array}$ & $\begin{array}{c}\text { Dis- } \\
\text { agreement } \\
\% \\
\end{array}$ & $\begin{array}{c}\text { Agreement } \\
\%\end{array}$ \\
\hline $\begin{array}{l}\text { 1. The outcomes identify the } \\
\text { graduate teacher students' } \\
\text { general English language } \\
\text { knowledge. }\end{array}$ & $8.55 \%$ & $91.45 \%$ \\
\hline $\begin{array}{l}\text { 2. The outcomes identify the } \\
\text { graduate teacher students' } \\
\text { English language } \\
\text { communicative skills. }\end{array}$ & $6.58 \%$ & $93.42 \%$ \\
\hline $\begin{array}{l}\text { 3. The outcomes identify the } \\
\text { graduate teacher students' } \\
\text { English language } \\
\text { competency (C1). }\end{array}$ & $11.18 \%$ & $88.82 \%$ \\
\hline $\begin{array}{l}\text { 4. The outcomes identify the } \\
\text { graduate teacher students' } \\
\text { employability. }\end{array}$ & $12.58 \%$ & $87.42 \%$ \\
\hline $\begin{array}{l}\text { 5. The outcomes clearly } \\
\text { identify the graduate teacher } \\
\text { students' professional } \\
\text { practical experience } \\
\text { requirements within high } \\
\text { school and other teaching } \\
\text { sites. }\end{array}$ & $21.33 \%$ & $78.67 \%$ \\
\hline
\end{tabular}




\subsection{The participants' perceptions of the curriculum preparations for graduates' English Language Knowledge standards}

A large number of the surveyed lecturers indicated their high rate of agreement with the alignment of curriculum and English language standard, at 90.85\%. Participants agreed with the principle that their institutions' curriculum provided students with sufficient English language knowledge. The document analysis findings illustrated a variety of English language major courses among the curricula of the participating institutions. Students were provided with English Linguistics, Contextualised grammar, Phonetics and Phonology, Lexicology, Pragmatics and Discourse Analysis, English - Vietnamese Linguistics, and Semantics in major courses. In addition, some curricula placed a significant focus on linguistics knowledge. Therefore, knowledge of English language is prepared with a variety of English major courses (Table 2)

Table 2: Participants' perceptions of the alignment between curriculum and MoET's standards

\begin{tabular}{|l|c|c|}
\hline $\begin{array}{c}\text { Do you agree or disagree } \\
\text { with the following } \\
\text { statements? }\end{array}$ & $\begin{array}{c}\text { Dis- } \\
\text { agreement } \\
\%\end{array}$ & $\begin{array}{c}\text { Agreement } \\
\%\end{array}$ \\
\hline $\begin{array}{l}\text { 1. The curriculum aligns with } \\
\text { the MoET's requirements of } \\
\text { general English language } \\
\text { knowledge. }\end{array}$ & $9.15 \%$ & $90.85 \%$ \\
\hline $\begin{array}{l}\text { 2. The curriculum aligns with } \\
\text { the MoET's requirements of } \\
\text { English language } \\
\text { communicative skills. }\end{array}$ & $11.18 \%$ & $88.82 \%$ \\
\hline $\begin{array}{l}3 . \quad \text { The curriculum aligns with } \\
\text { the MoET's requirements of the } \\
\text { graduate students' education } \\
\text { workplace skills. }\end{array}$ & $15.69 \%$ & $84.31 \%$ \\
\hline $\begin{array}{l}4 . \quad \text { The curriculum has } \\
\text { sufficient courses to } \\
\text { adequately prepare graduate } \\
\text { teacher students' instruction in } \\
\text { English. }\end{array}$ & $17.65 \%$ & $82.35 \%$ \\
\hline $\begin{array}{l}5 . \text { The curriculum aligns with } \\
\text { the MoET's requirements of } \\
\text { English language competency } \\
\text { (C1). }\end{array}$ & $22.37 \%$ & $77.63 \%$ \\
\hline $\begin{array}{l}\text { 6. The theory and practice } \\
\text { courses are well balanced. }\end{array}$ & $24.84 \%$ & $75.16 \%$ \\
\hline $\begin{array}{l}7 . \text { The curriculum has sufficient } \\
\text { opportunities to adequately } \\
\text { provide professional practical } \\
\text { experiences within high school } \\
\text { and other teaching sites, for } \\
\text { graduate students. }\end{array}$ & $30.26 \%$ & $69.74 \%$ \\
\hline \multicolumn{1}{|c|}{. } & \\
\hline
\end{tabular}

\subsection{The participants' perceptions of the curriculum preparations for graduates' English Language Proficiency (ELP) skills standards}

Concerns about the level of the alignment between institutional curriculum and MoET's standards in terms of English language competency (the $\mathrm{C} 1$ level) have been indicated by lecturers and administrators.

Limited time allocated for the English language major courses was reported by a majority of participants. They felt the current course timetabling within the curriculum was poorly organised, which led to a lack of time for English language courses. They also perceived that the curriculum spent too much time on general knowledge courses, therefore not enough time on language major courses. Nearly one third of participating lecturers did not satisfy with the class time for students to practice English language skills. The informants claimed about an imbalance between the time dedicated to practice and theory lectures as a reason for their ineffective curriculum. Participating lecturers recommended reduce time allocated for general courses and spend more time for English language practice.

\subsection{The participants' perceptions of the curriculum preparations for graduates' Employability standards}

Employability standards refer to graduates' possible career options. Following the requirements, graduates must be prepared to teach in all sectors of Vietnamese education system, especially high schools. The requirements include working as lecturers and researchers in higher education. In addition, graduates are required to show autonomy and responsibility in their future careers. They are also required to be able to adapt to variable working conditions [17]. The participants stated that ELTE programs provided sufficient knowledge (foundation, English language, and pedagogy), but they did not emphasise sufficient employability skills.

The surveyed and interviewed lecturers were not confident with the alignment between curriculum and standards in terms of employability standards. They indicated their much concern about their students' practical knowledge of high school and other educational working sites. The surveyed respondent also expressed their concerns of the poor preparation for the graduates' workplace skills. $69.74 \%$ of the respondents agreed with the principle that the curriculum has sufficient opportunities to adequately provide professional practical experiences within high school and other teaching sites, for graduate students (Table 2). 
ELTE programs provided students with professional experience courses in high schools. Professional experience courses occurred in the last semester of the third and fourth years of the programs. Professional experience was mentored by a high school teacher. Some institutions provided staff members to supervise students. The data analysis showed that among the eleven participating institutions, on average, professional experience courses only made up $4.09 \%$ of the total program. The limited time and courses spent on preparing students with professional experience may prevent students from meeting employability skills standards.

The respondents suggested adding some more courses to help students understand working conditions after graduation. They recommended provide students with knowledge and time of practicing teaching at high schools and other educational sites where they may be employed after graduation.

\section{Discussions}

The findings illustrated both strong and weak alignment between curriculum, outcomes, and standards of ELTE programs. There is good alignment between institutional expected outcomes and MoET's standards. In other words, MoET's requirements of English language knowledge, English language proficiency skills, and employability skills have been well identified in the institutional outcomes. However, curriculum, outcomes and standards are not always aligned. They are strongly aligned in terms of English language knowledge, but weakly aligned in terms of English language proficiency and employability skills.

The study also revealed that MoET's standards of English language proficiency are higher than the ELTE students' capacity across all participating institutions, although those requirements are clearly identified in the institutional outcomes. In other words, the $\mathrm{C} 1$ level standard is perceived unachievable because of the low levels of students when they entered into the ELTE programs. The study finding confirms previous Vietnamese research that Vietnamese students' English language competence is low [7] [18] and the National Foreign Language Project 2020 has failed to achieve its goals [5] [6] [19].

\section{Recommendations}

The study findings suggest a weak alignment between current ELTE curriculum and standards in terms of skills and employability. It should be recommended that lecturers and instructional leaders should be trained with curriculum alignment. Provision of knowledge and skills about how to align curriculum, pedagogy, and assessment with outcomes and standards may be considered. The participants' misperception of the alignment of assessment, curriculum, and standards may possibly be explained by lecturers misunderstanding what alignment actually is.

In addition, professional development about standards may be considered because MoET's standards were perceived as unattainable. Professional development about standards and alignment may assist lecturers to become aware of the necessity of preparing students to address institutional expectation and national standards.

The Vietnamese government and MoET may consider supporting research to investigate the requisite number of credit hours needed for students with low entry ELP to achieve graduation standards. Research about investigation of the requisite number of credit hours could be particularly important to provide provincial students with opportunities to improve ELP. Institutions may consider paying for lecturers who provide extra time to help less proficient students.

\section{Conclusion}

To address the gaps and make the researched elements more aligned, all curriculum stakeholders should be encouraged to engage on process of negotiation and collaboration on the development of vision for change. The curriculum and outcomes should be designed and/or redesigned based on MoET's standards. The institutions may consider providing more courses and time for the ELP courses in the current curriculum. The ministry and institutions may also consider providing more professional development programs to lecturers and instructional leaders in terms of English language proficiency and curriculum design.

Developing outcomes and designing curriculum based on standards are crucial to make them more aligned with standards and improve students' outcomes. Institutions may consider increasing investment in curriculum development and employing more experienced and well-trained staff and providing them with greater time to devise outcomes. My findings suggest that institutions faced time limitations and lack of capacity to design outcomes. The writers of outcomes should consider using simple and unambiguous terms to express all MoET's requirements clearly, so that administrators, lecturers, students, and employers can understand them well, as suggested by international scholars [20].

In summary, restructuring the ELTE curriculum in line with institutional outcomes and MoET's standards should be considered. Curriculum could be revised with a stronger focus on practice. More emphasis on softskills, research skills, and assessments may help fill the 
gaps between curriculum and standards. More opportunities for students to facilitate their employability may also be helpful. Refocusing curriculum and placing more emphasis on ELT by reevaluating the program may help unburden the curriculum.

\section{References}

[1] Decision No.1400/QD-TTg. (2008). Quyết định số 1400/QĐ-TTg về viêc Phê duyệt đề án "Dạy và học ngoại ngũ trong hệ thổng giáo dục quốc dân giai đoạn 2008-2020" [Decision No.1400/QD-TTg on the Approval of the Project entitled "Teaching and Learning Foreign Languages in the National Education System, Period 2008-2020]. The Government of Vietnam Retrieved from https://thukyluat.vn/vb/quyet-dinh-1400-qd-ttg-de-an-dayhoc-ngoai-ngu-trong-he-thong-giao-duc-quoc-dan-20082020-115fo.html.

[2] Nguyen, D. K., \& Phan, T. T. V. (2016). An Investigation to Vietnamese Educational System: A View from History and Paulo Freire's Pedagogy of The Oppressed. Papers of Social Pedagogy, 82-97. Retrieved from https://www.researchgate.net/publication/311571725_An_In vestigation_to_Vietnamese_Educational_System_A_View_F rom_History_and_Paulo_Freire's_Pedagogy_of_The_Oppres sed

[3] Nguyen, V. N., \& Mai, N. K. (2015). Responses to a Language Policy: EFL Teachers' Voices. The European Journal of Social and Behavioural Sciences XIII. doi: http://dx.doi.org/10.15405/ejsbs.164e.

[4] Tran, T. L., Le, T. T. T., \& Nguyen, T. N. (2014). Curriculum and Pedagogy. In L. Tran, S. Marginson, H. Do, Q. Do, T. Le, N. Nguyen, T. Vu, T. Pham, \& H. Nguyen (Eds.), Higher Education in Vietnam: Flexibility, Mobility and

Practicality in the Global Knowledge Economy (pp. 86-107). London, England: Palgrave MacMillan.

[5] Dân trí. (29 January, 2017). Điều chỉnh Đề án Ngoại ngũ 2020 và kéo dài đến 2025 [Adjusting the National Foreign Languages Project 2020 and lasting till 2025]. Dân trí. Retrieved from https://dantri.com.vn/giao-duc-khuyenhoc/de-an-ngoai-ngu-2020-that-bai-dieu-chinh-va-keo-daiden-2025-20171229155520734.html.

[6] Người Lao Động. (07 May, 2017). Đề án ngoại ngữ 9.300 tỉ không về đích!? [The 9,300 billion National Foreign Languages Project cannot achieve the goals]. Nguoòi Lao Động. Retrieved from https://tintaynguyen.com/de-an-ngoaingu-9300-ti-khong-ve-dich/327120/.

[7] Nguyen, M. H. (2013). The Curriculum for English Language Teacher Education in Australian and Vietnamese Universities. Australian Journal of Teacher Education, $38(11), 22$.
[8] Bui, T., Nguyen, T. T. T., \& Nguyen, D. A. (2018) Vietnamese higher education language planning and university students' career development. In J. Albright (Ed.), English Tertiary Education in Vietnam (pp. 54-67). London, England: Routledge.

[9] Bilsland, C., Nagy, H., \& Smith, P. (2014). Planning the Journey to Best Practice in Developing Employability Skills: Transnational University Internships in Vietnam. Asia-Pacific Journal of Cooperative Education, 15(2), 145-157. Retrieved from https://researchbank.rmit.edu.au/view/rmit:24751.

[10] Tran, T. T. (2015). Is graduate employability the "wholeof-higher-education-issue'? Journal of Education and Work, 28(3), 207-227. doi:10.1080/13639080.2014.900167.

[11] Truong, T. T. H., S. Laura, R., \& Shaw, K. (2018). The Importance of Developing Soft Skill Sets for the Employability of Business Graduates in Vietnam: A Field Study on Selected Business Employers. Journal of Education and Culture Studies, 2(1), 32-45. doi:10.22158/jecs. V2n1p32.

[12] Nguyen, T. P. L. (2019). Alignment of Curricula, Pedagogies, Assessments, Outcomes, and Standards in Vietnamese English Language Teacher Education. (Doctoral). The University of Newcastle.

[13] Law No.08/2012/QH13. (2012). Luật số 08/2012/QH13 Luật Giáo duc đại học [Law No.08/2012/QH13 on Higher Education]. The Government of Vietnam Retrieved from https://thuvienphapluat.vn/van-ban/Giao-duc/Luat-Giao-ducdai-hoc-2012-142762.aspx.

[14] Directive No.2196/BGDĐT-GDDH. (2010). Chi thi 2196/BGDĐT-GDĐH Hướng dẫn xây dưng và công bố chuẩn đầu ra các ngành đào tạo [Directive No. 2196/BGDĐTGDDH of April 22, 2010 on building and publishing the Training program Outcomes]. Ministry of Education and Training of Vietnam Retrieved from http://thuvienphapluat.vn/cong-van/Giao-duc/Cong-van2196-BGDDT-GDDH-cong-bo-chuan-dau-ra-nganh-dao-tao104676.aspx.

[15] Decision No.2080/QĐ-TTg. (2017). Quyết định số 2080/QĐ-TTg Phê duyệt điều chỉnh, bổ sung Đề án Dạy và hoc Ngoại ngũ trong hẹ thống giáo duc quốc dân giai đona 2017-2025 [Decision 2080/QD-TTg on the Approval of Adjustment and Supplement the Project entitled "Teaching and Learning Foreign Languages in the National Education System, Period 2017-2025"]. The Government of Vietnam Retrieved from https://thuvienphapluat.vn/van-ban/Giaoduc/Quyet-dinh-2080-QD-TTg-2017-bo-sung-De-an-dayhoc-ngoai-ngu-trong-he-thong-giao-duc-quoc-dan370658.aspx.

[16] Smit, B. (2003). Can Qualitative research inform policy implementation? Evidence and Arguments from a developing country context. Qualitative Social Research, 4(3).

[17] Circular No.07/2015/TT-BGD DT. (2015). Thông $t u$ 07/2015/TT-BGDĐT ban hành Quy định về khối lương kiến 
thức tối thiểu, yêu cầu về năng lục mà người học đạt được sau khi tốt nghiệp đối với mỗi trình độ đào tạo của GDĐH và quy trình xây dựng, thẩm định, ban hành CTĐT trình độ đại học, thac sĩ, tiến sĩ [Circular 07/2015/TT-BGD DT promulgating the regulation on minimum amount of knowledge, required capacity of graduates at each training level of $H E$ and procedure of training program for university level, master's level and doctorate level]. Ministry of Education and Training of Vietnam Retrieved from http://vanban.chinhphu.vn/portal/page/portal/chinhphu/hetho ngvanban?class_id $=1$ mode $=$ detail\&document_id $=179801$.

[18] Do, M. H., \& Do, T. N. Q. (2014). Higher and Tertiary Education in Vietnam. In L. Tran, S. Marginson, H. Do, Q. Do, T. Le, N. Nguyen, T. Vu, T. Pham, \& H. Nguyen (Eds.), Higher Education in Vietnam Flexibility, Mobility and Practicality in the Global Knowledge Economy (pp. 29-53). London, England: Palgrave MacMillan.

[19] Le, V. C., \& Nguyen, T. N. (2017). Đề án Ngoại ngũu Quốc gia có thể học gì tù kinh nghiệm Châu Á ? [The National Foreign Language Project 2020 can learn from Asean experience?]. VNU Journal of Foreign Studies, 33. doi:10.25073/2525-2445/vnufs.4166.

[20] Kennedy, D. (2006). Writing and using learning outcomes: a practical guide. Cork, Ireland: University College Cork. 